Johnson \& Wales University

ScholarsArchive@JWU

Health \& Wellness Department Faculty

Publications and Research

College of Health \& Wellness

2011

Electronic cigarettes: a new 'tobacco' industry?

Jonathan K. Noel

Vaughan W. Rees

Gregory N. Connolly

Follow this and additional works at: https://scholarsarchive.jwu.edu/health_fac

Part of the Medicine and Health Sciences Commons 


\title{
Electronic cigarettes: a new 'tobacco' industry?
}

\author{
Jonathan K Noel, Vaughan W Rees, Gregory N Connolly
}

Center for Global Tobacco Control, Department of Society, Human Development \& Health Harvard School of Public Health, Boston, USA

\section{Correspondence to}

Vaughan Rees, Harvard School of Public Health, Global Center for Tobacco Control, Landmark Building, Level 3 East 677 . Huntington Ave Boston, MA 02115, USA:

vrees@hsph.harvard.edu

Received 23 June 2010 Accepted 11 August 2010 Published Online First 7 October 2010
Electronic cigarettes (e-cigarettes) have gained considerable attention since their introduction into European and American markets in 2006 and 2007, respectively. Research to date has focused on acute exposure, $^{12}$ nicotine delivery ${ }^{1-3}$ and consumer response, ${ }^{4}$ yet little information has so far been available on this new and rapidly developing industry. Knowledge of e-cigarette sales and marketing strategies is needed to fully inform responses from the tobacco control community, including consideration of product regulation. ${ }^{5}$

In the USA, e-cigarette promotion has coalesced around three organisations. The Electronic Cigarette Association 'was founded to institute and promote industry-wide standards and a code of conduct, work to maintain sound professional and practices, educate the public and policy-makers on the industry's activities and potential, and ensure the ethical use of electronic cigarette technologies' (http:// www.ecassoc.org/electronic-cigarette-associationbylaws/). The Consumer Advocates for Smoke-Free Alternatives Association was created to advocate for harm reduction and sustained nicotine use as an alternative to smoking and tobacco cessation (http:// www.casaa.org), and Vapers International Inc. is an e-cigarette industry research organisation, who, according to their website, has utilised the services of several tobacco control scientists and advocates (http://vapersinternational.org/). E-cigarette stakeholders have claimed success after advocacy efforts in Illinois resulted in postponement of voting on a bill to ban e-cigarette sales (http://www.casaa.org/news/ article.asp? articleID $=98 \& \mathrm{l}=\mathrm{a} \& ; \mathrm{p}=)$, and in Virginia, where the Attorney General determined that e-cigarettes were not included in the state smoking ban (http://www.casaa.org/news/article.asp?articleID =99 $\& \mathrm{l}=\mathrm{a} \& ; \mathrm{p}=)$.

E-cigarette marketing has occurred mainly through the internet. Some e-cigarette companies, such as SmokeStik and Totally Wicked, have created webpages on the social networking site Facebook (http://www.facebook.com). Others, including Gamucci and Green Smoke, have used YouTube.com to post promotional videos and many e-cigarette users have posted personal videos displaying their use of the product. E-cigarette companies have also advertised on the search engine websites Google, Yahoo and MSN. Other ecigarette marketing includes the use of contests and giveaways. E-Cigarettes National has provided entry into a raffle for gift certificates, cash and a TV with product purchase. Additionally, industrysponsored internet forums are used to guide naïve users and promote e-cigarette use. As of August 2010, E-cigarette Forum (www.e-cigarette-forum. com) was sponsored by 81 e-cigarette companies and claims to have over 41000 members. Posts on the website include product reviews; instructions on how to use an e-cigarette; directions to modify e-cigarettes; and information regarding new contests, events and advocacy efforts.

Considerable press has emphasised the rapid spread and popularity of the product, even though the ecigarette industry is relatively new and US sales have occurred primarily through the internet. However, a growing presence of e-cigarettes at shopping mall kiosks has been observed, and the US company Sottera Inc. has engaged with distributors to sell the NJOY brand of e-cigarettes in Pilot gas stations throughout the USA (http://www.njoy.com/NJOYLaunched-in-Retail-Stores-by-TSC). In the UK, Intellicig recently announced a deal with distributor Innzone to place e-cigarettes in stores throughout the UK (http://uk.prweb.com/releases/2010/02/prweb 3548144.htm). In January 2009, Ruyan Group Ltd. reported annual worldwide revenue of approximately \$US54 million (http://investing.businessweek.com), while Vapor Corp reported $\$ 7.95$ million in sales in the USA. ${ }^{6}$ In comparison, the tobacco industry generated an estimated $\$ 50$ billion from sales of light cigarettes in 2009.?

The emergence of the e-cigarette industry must be met with an informed public health response. Research on product design, toxicant exposure, abuse liability including dual use with tobacco products, youth initiation, and influence on cessation efforts is needed to counteract e-cigarette industry marketing and inform regulatory strategies.

Funding National Cancer Institute grant \# 1R01-CA-125224.

\section{Competing interests None.}

Provenance and peer review Not commissioned; externally peer reviewed.

\section{REFERENCES}

1. Eissenberg T. Electronic nicotine delivery devices: ineffective nicotine delivery and craving suppression after acute administration. Tob Control 2010:19:87-8.

2. Vansickel AR, Cobb CO, Weaver MF, et al. A clinical laboratory model for evaluating the acute effects of electronic 'Cigarettes': nicotine delivery profile and cardiovascular and subjective effects. Cancer Epidemiol Biomarkers Prev 2010;19:0F1-9.

3. Bullen C, McRobbie H, Thornley S, et al. Effect of an electronic nicotine delivery device (e cigarette) on desire to smoke and withdrawal, user preference and nicotine delivery: randomized cross-over trial. Tob Control 2010;19:98-103.

4. Etter JF. Electronic cigarettes: a survey of users. BMC Public Health 2010;10:231-8.

5. Henningfield JE, Zaatari GS. Electronic nicotine delivery systems: emerging science foundation for policy. Tob Control 2010;19:89-90.

6. United States Securities and Exchange Commission. Form 10-K Vapor Corp. Washington, DC 2010. http://www.sec.gov/ Archives/edgar/data/844856/000095012310030980/c98669e10vk. htm (accessed 5 Apr 2010)

7. ACNielsen. ScanTrack Retail Measurement, cigarette category, mass merchandiser channel, Total U.S. market, 2009. Schaumberg, IL, 2009. 